\title{
The desmids of the Swamp Nature Reserve (North Bohemia, Czech Republic) and a small neighbouring bog: species composition and ecological condition of both sites
}

\author{
Jan ŠŤASTNÝ \\ Department of Botany, Charles University, Prague, Benátská 2, CZ - 12801 Praha, Czech Republic
}

\begin{abstract}
The present study is a summary of recent findings concerning the desmid flora of the Swamp Nature Reserve and a small neighbouring bog. A total of 203 desmid taxa belonging to 22 genera were found, including 39 taxa that are considered very rare in the Czech Republic. Of this number, 46 taxa were found in the Swamp and 203 taxa in the neighbouring bog.

The ecological condition of both localities was assessed on the basis of the species composition of the desmid communities encountered. The results indicate that the present overall ecological situation of the Swamp is favourable for the development of a characteristic, acidophilous desmid community. They also document quite an exceptional natural value of the second site studied, fully justifying its recent designation as part of the Swamp Nature Reserve. The results presented here may also be used in the future as a basis for comparative ecological studies tracing the development of both these sites.
\end{abstract}

Key words: bioindicators, desmids, ecology, species diversity, Swamp Nature Reserve

\section{Introduction}

The Swamp Nature Reserve, designated as such in 1972, has been the subject of algological investigations since the beginning of the $20^{\text {th }}$ century. The scientific activities of the prominent German algologist A. Pascher were closely connected with the Swamp; he published several studies focused on chrysophytes (PASCHER 1909) and heterokontophytes (PASCHER 1939). Pascher's student, F. Mattauch, published a very detailed and comprehensive study of the locality (Mattauch 1936). The site is well- known due to the occurrence of two rare representatives of Synurophyceae: Mallomonas ouradion K.HARRIS et D.E.BRADLEY and Mallomonas matvienkoae B.Asmund et Kristiansen (Kalina 1969, Asmund \& KRISTIANSEN 1986). It was a rich source of material for taxonomic studies on dinophytes (Pfiester \& Popovský 1979, Popovský \& Pfiester 1990) and the green alga Dicranochaete bohemica was also firstly described from here (NovÁKovÁ \& PoPOVSKÝ 1972). The diatom flora of the locality was investigated by STOJANOVSKI \& KALINA (1989). The latest paper dealing with the algal flora of the Swamp so far is by KaLINA \& PunČOCHÁŘovÁ
(1996).

Despite being one of the dominant algal groups, the desmids of the Swamp have not been investigated in detail so far. However, among the 195 algal taxa found Mattauch (1936) also mentions 55 taxa of desmids. KaLINA \& PunČOCHÁŘová (1996) found 25 desmid taxa, but since many taxa were obviously misidentified, their data should be considered with much reserve.

To my knowledge the second site studied, a small bog adjacent to the Swamp, has not yet been the object of any algological investigation so far.

Desmids are particularly important indicators of wetland ecosystems due to their highly specific ecological demands (see e.g. COESEl 1998, 2001, 2003, ŠŤASTNÝ 2005, HAŠLER et al. 2008). The main aim of the present study was therefore to summarize recent knowledge of the desmid flora of both sites and to evaluate the current ecological condition of these ecosystems on the basis of the species composition of the desmid communities. Another aim of the study was to evaluate the changes of the Swamp desmid flora over the last 70 years by comparing my data with the data of MATTAUCH (1936), in particular 
with respect to possible eutrophication of the locality with alkaline lake water and the subsequent degradation of the sensitive acidophilous flora.

\section{Locality}

Both localities studied are situated in Northern Bohemia about $1.5 \mathrm{~km}$ northeast of the town of Doksy, in the south-eastern part of the Máchovo jezero lake (Mácha's lake) at an altitude of 265 meters a.s.l (see Fig.1). They lie in small bays which are remnants of an original bank of a glacial lake. Their bottoms are covered with Sphagnum, in particular Sphagnum auriculatum Schimp. (NovÁKovÁ \& Popovský 1972). Both localities developed in the $14^{\text {th }}$ century due to a rise of groundwater level after the lake was founded.

The Swamp Nature Reserve (total area of 1.45 ha, GPS $50^{\circ} 34^{\prime} 48.19^{\prime \prime} \mathrm{N}, 14^{\circ} 40^{\prime} 4.77^{\prime \prime} \mathrm{E}$ ) is a transitional bog and its water regime depends on the lake water level (Kalina \& Punčochár̆ová 1996). Nearly the whole area of the Swamp is covered with Sphagnum sp. and the water is oligotrophic and strongly acidic $(\mathrm{pH}=3.5-4.6)$; only a small part of the locality is rather oligomesotrophic and less acidic $(\mathrm{pH}=5.1-5.4)$ due to overgrowing by Phragmites australis (CAV.) TRIN ex STEUd. In the southern part of the Swamp there are copious stands of Utricularia minor L. and Nymphaea candida PRESL. The conductivity values measured ranged between 88 and $174 \mu \mathrm{S} . \mathrm{cm}^{-1}$. The Swamp is separated from the lake by a narrow reinforced dam that should prevent disturbance of the locality by the eutrophic and alkaline $(\mathrm{pH}=7.5-8.0)$ lake water.

The second site studied (total area of ca $2.5 \mathrm{ha}$ ) is situated about $350 \mathrm{~m}$ south-southeast of the Swamp, in the so-called Břehyňská Bay, north of the Břehyňský stream inflow into the lake (GPS 50³4'34.44" N, $\left.14^{\circ} 40^{\prime} 14.45^{\prime \prime} \mathrm{E}\right)$. It is a transitional bog and its water regime also depends on the lake water level. This locality, however, is more fragmented than the Swamp. There are distinct gradients of acidity and trophy. The most extensive eastern part of the locality, covered with Sphagnum sp., is oligotrophic and strongly acidic $(\mathrm{pH}=3.4-4.2)$ and in one pool extensive stands of Utricularia minor have developed. Closer to the lake this part gradually changes into a mesotrophic littoral reed belt. The reaction of the water in this part is slightly acidic $(\mathrm{pH}=5.0-6.3)$, there are a number of shallow pools filled in with Utricularia australis R.BR. and the littoral reed belt gradually merges into the lake. The conductivity values measured at this site ranged from 54 to $156 \mu \mathrm{S} . \mathrm{cm}^{-1}$.

This second site became a part of the newlyestablished Swamp Nature Reserve in June 2007. However, since the two localities have a somewhat different character and a completely different history concerning algological investigations, they are discussed separately in this paper.

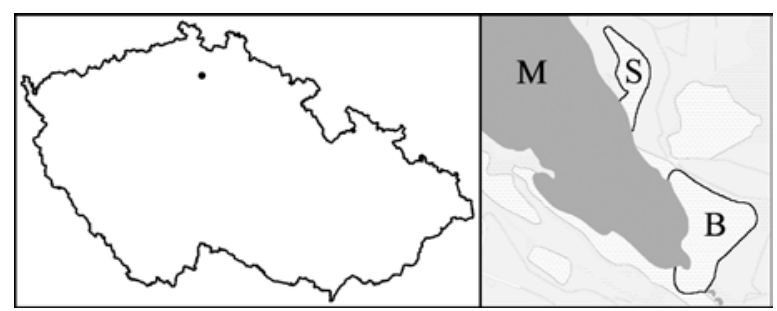

Fig. 1. Location of the sampling sites in the territory of the Czech Republic and in the south-eastern part of the Máchovo jezero lake [(M) Máchovo jezero lake; (S) Swamp; (B) neighbouring bog].

\section{Material and methods}

The algal material was collected in June 2005, May 2006 and in February and March 2007. Altogether, 72 samples were taken from both sites. The samples were collected by sucking off the algae from the sediment with a syringe and by squeezing out mosses (in particular Sphagnum sp.) and dominant aquatics (particularly Utricularia spp.). Shortly after sampling, part of the material was fixed with formaldehyde to a final concentration of about $4 \%$ and later used for semi-quantitative assessment according to the following relative scale: 1 - very rare; 2 - scattered; 3 - abundant; 4 - very abundant; 5 - mass occurrence. Light microscopic observations were done mostly on living material. Environmental variables $(\mathrm{pH}$, conductivity) were measured using a Combo HI 98129 portable instrument (HANNA, Germany), microphotographs were taken using an Olympus BX51 light microscope and Olympus Camedia C - 5050Z digital microphotographic equipment.

The relative rarity of the individual taxa within the Czech Republic was evaluated on the basis of the author's extensive personal experience and classified according to the following scale: 1 - scattered occurrence; 2 - rare taxon; 3 - very rare taxon. In general, taxa labelled as very rare in the Czech Republic are also rare in Central Europe (see e.g. RŮŽIČKA 1977, 1981, Gutowski \& Mollenhauer 1996, Lenzenweger 2003).

Detrended correspondence analysis (DCA) using Canoco for Windows 4.5 (TER BRAAK \& Šmilauer 1998) was done for statistic evaluation. The evaluation focused on the differences in species composition between the sampling sites. The basic detrending analysis was carried out with respect to downweighting of rare species.

\section{Results}

A total of 203 desmid taxa belonging to 22 genera were identified; 46 taxa were found in the Swamp and 203 taxa in the neighbouring bog (Table 1). 
Eight taxa (Closterium lineatum, Cosmarium margaritiferum, Cylindrocystis brebissonii, Hyalotheca dissiliens, Penium spirostriolatum, Staurastrum teliferum, Staurodesmus extensus var. isthmosus and Xanthidium armatum) were found forming zygospores.

\section{The Swamp}

The species composition of the desmid communities from the Swamp corresponds well with the very low $\mathrm{pH}$ of the water. Most species found may be characterized as strictly acidophilous; the dominant species (Cylindrocystis brebissonii, Tetmemorus laevis, Closterium striolatum, Staurastrum punctulatum, St. simonyi) belong to the most common acidophilous desmids, frequently occurring in all kinds of strongly acidic water bodies. The extreme milieu conditions were also reflected by the generally rather poor species richness of the site as a whole as well as by the poor species richness of the individual samples, which ranged from 2 to 11 taxa per sample and slightly increased up to 18 taxa per sample only in the eutrophic part with overgrowing Phragmites australis. This local increase in the trophic state was also reflected in the presence of several taxa preferring oligomesotrophic (Closterium baillyanum, Cl.juncidum, Cosmarium amoenum, C. pseudopyramidatum, Micrasterias truncata) or even mesotrophic conditions (Euastrum ansatum, Staurastrum lapponicum, Cosmarium quadratum, Closterium parvulum).

The taxa Cosmarium botrytis var. mediolaeve and Cosmarium cf. tenue prefere mesotrophic or slightly eutrophic conditions and obviously are not autochtonous in the Swamp and originate most likely from the lake littoral zone. This hypothesis is also supported by the fact that they have been found near the lake and in a minimal abundance (one cell of each species).

The most rare and interesting findings are Micrasterias jenneri, Euastrum luetkemuelleri var. carniolicum, Cosmarium prominulum var. subundulatum, C. subquadrans var. minor and Actinotaenium perminutum. The finding of a robust form of the rather recently described and very rare Haplotaenium indentatum (KouwETs 1991) is also remarkable.

\section{The small bog}

The composition of the desmid communities from the second site studied is distinctly determined by the $\mathrm{pH}$ and trophy gradients. In its eastern, oligotrophic and strongly acidic part basically two main types of habitats may be distinguished. The very shallow, periodically desiccating pools are dominated by adaptive, frequently dividing species (in particular Cylindrocystis brebissonii, Tetmemorus laevis, Actinotaenium cucurbita and Closterium striolatum). On the other hand, large species with a much lower growth rate (COESEL 1982), e.g. Micrasterias jenneri, M. oscitans, M. truncata, Cosmarium ralfsii or Xanthidium armatum, require deeper pools with a more stable water regime for their development. The species richness of the samples from this part of the locality is rather poor, comprising mostly 10-20 desmid taxa (the highest number generally occurring in deeper, stable pools). However, the abundance of those particular taxa is generally very high and the majority of the species mentioned occur locally in great mass (see Fig. 2).

The species richness on the transect from the oligotrophic, strongly acidic part of the site to the lake sublittoral exhibits a characteristic pattern influenced by the $\mathrm{pH}$ and trophy gradient: transitional, oligomesotrophic zone with 2030 taxa, slightly acidic, mesotrophic zone with up to 90 taxa and eutrophic lake sublittoral 32 taxa. However, with the increasing species richness the abundance of the individual taxa in a sample decreases and hence also the number of the characteristic taxa (see Fig. 2). Typical representatives of the transitional, oligomesotrophic zone are e.g. Closterium baillyanum, Cosmarium pyramidatum, C. pseudopyramidatum, $C$. tinctum, Penium cylindrus and Haplotaenium rectum. The mesotrophic, slightly acidic littoral zone is characterized by the co-occurrence of many generally rare taxa, and moreover in this part of the locality it is even possible to find some representatives of the eutrophic lake tychoplankton (e.g. Closterium venus, Staurastrum eurycerum, Cosmarium humile, C. wittrockii, C. reniforme, C. subgranatum, etc.).

The ordination diagram (Fig. 2), which includes the samples from 2005 and 2006, illustrates the situation in the bog. The first two of the DCA ordination axes explained 26.2 and $5.7 \%$ of the variance of the species data, respectively. The first ordination axis represents the $\mathrm{pH}$ gradient with acidic sites on the left. This is in accordance with the data published by COESEL (1998) and ŠŤASTNÝ (2007), who consider the water $\mathrm{pH}$ the key factor influencing desmid distribution. The factor being responsible for the distribution of the samples 


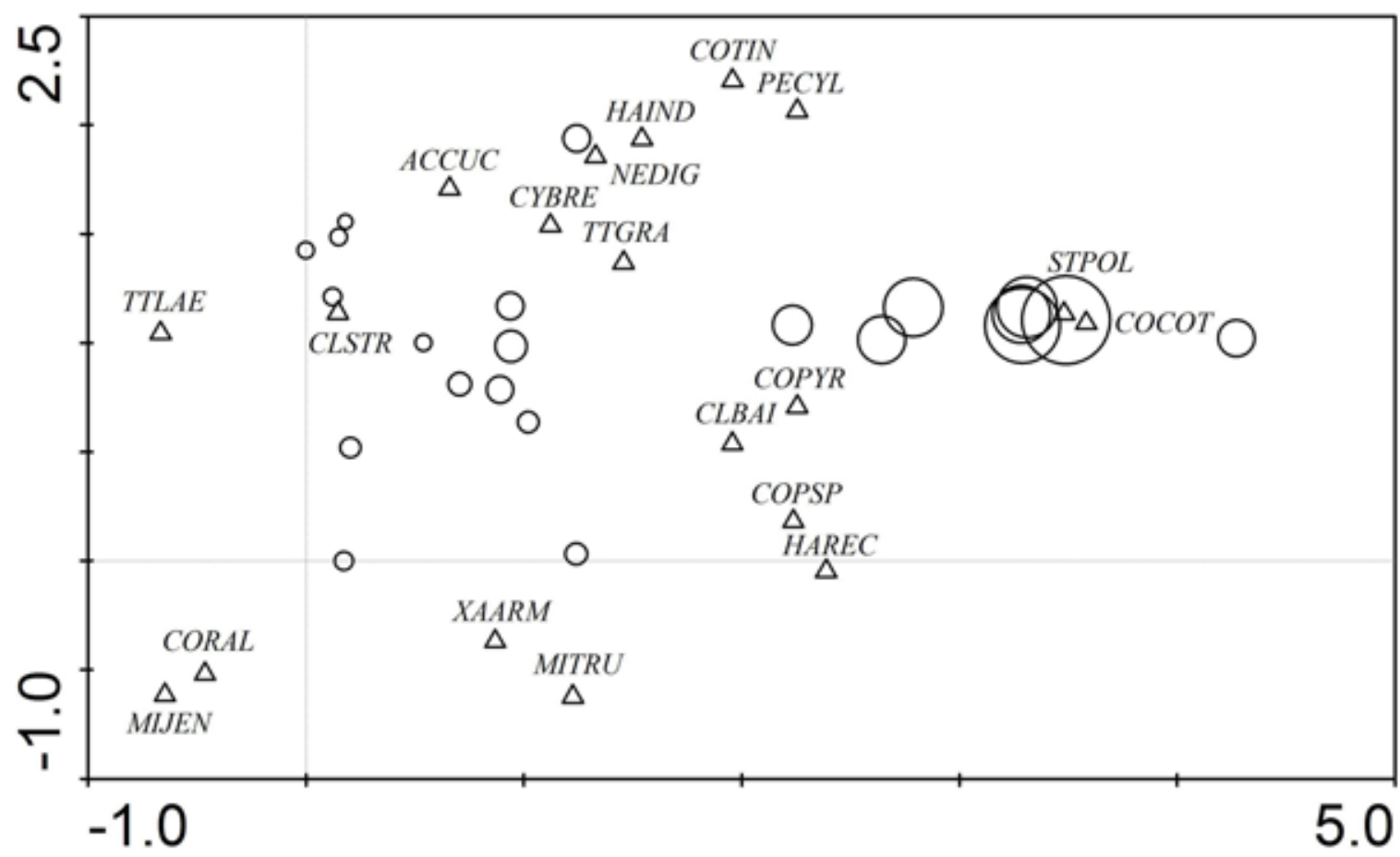

Fig. 2. The results of DCA from site 2 (the bog) in the ordination space of the first two axes (circles = samples; triangles = species). The size of the circles correlates with the species richness of the samples. Only the statistically most relevant species are depicted. Taxon abbreviations: (ACCUC) Actinotaenium cucurbita; (CLBAI) Closterium baillyanum; (CLSTR) Cl. striolatum; (COCOT) Cosmarium contractum; (COPSP) C. pseudopyramidatum; (COPYR) C. pyramidatum; (CORAL) C. ralfsii; (COTIN) C. tinctum; (CYBRE) Cylindrocystis brebissonii; (HAIND) Haplotaenium indentatum; (HAREC) H. rectum; (MIJEN) Micrasterias jenneri; (MITRU) M. truncata; (NEDIG) Netrium digitus; (PECYL) Penium cylindrus; (STPOL) Staurastrum polymorphum; (TTGRA) Tetmemorus granulatus; (TTLAE) T. laevis; (XAARM) - Xanthidium armatum.

with similar $\mathrm{pH}$ values is most likely the depth of the pools. The samples depicted in the lower part of the ordination diagram were taken from generally deeper pools than the samples depicted in the upper part of the diagram.

From the total of 203 taxa occurring in the bog, 102 taxa may be marked as more or less rare in the Czech Republic, 39 of those even as very rare (see Table 1). The most interesting findings are depicted below (Fig. 3, Fig. 4).

\section{Discussion}

Desmids are excellent bioindicators, not only with respect to their preference for certain environmental conditions but also with respect to the current ecological condition and stability of the given ecosystem (COESEL 1998, 2001). In particular due to their highly specific ecological demands, desmids have recently become the most endangered group of aquatic microorganisms, at least in densely populated countries (COESEL 1998). During the last decades, many cases of deterioration of previously rich desmid sites have been reported as a result of processes like eutrophication, acidification, desiccation or cultivation. The situation in the Netherlands is documented by CoEsel et al. (1978) and Coesel (2003). Lenzenweger (1996) notes the same phenomenon in Austria and ŠIMEK (1997) documents very convincingly the drastic influence of eutrophication on the desmid communities at the famous Czech algological site Řežabinec.

The high susceptibility of desmids to milieu changes and their short generation time make them very suitable (in contrast to vascular plants) to monitor short-term environmental changes. Particularly in the Netherlands, desmids have recently been used as bioindicators for the assessment of water quality and, in a number of nature restoration projects, for the assessment of nature conservation value (see e.g. COESEL 2003).

With respect to the above-mentioned information, it was very interesting to compare the current desmid flora of the Swamp with the data published by MATTAUCH (1936), in particular as regards the potential threat posed to the site by 

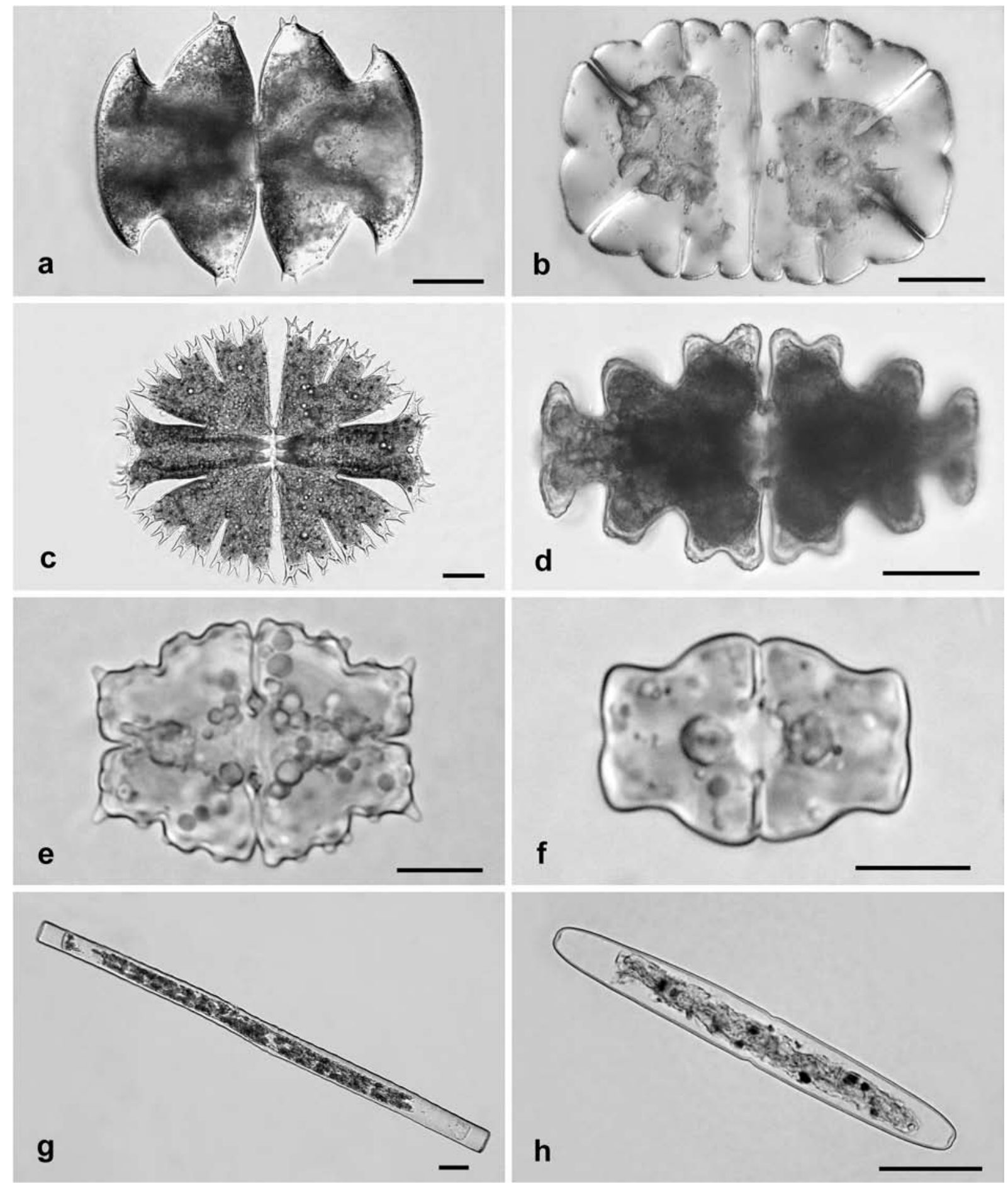

Fig. 3. (a) Micrasterias oscitans; (b) M. jenneri; (c) M. apiculata; (d) Euastrum pinnatum; (e) E. turneri; (f) E. luetkemuelleri var. carniolicum; (g) Pleurotaenium simplicissimum; (h) Haplotaenium indentatum, morpha. Scale bar $30 \mu \mathrm{m}$; e, f $10 \mu \mathrm{m}$.

the eutrophic lake water.

\section{The Swamp}

Whereas the vast majority of the 46 taxa that have been recently found at the Swamp may be characterized as strictly acidophilous, preferring strongly acidic, oligotrophic waters (see above), approximately 20 taxa mentioned by MATTAUCH
(1936) are more typical of mesotrophic, slightly acidic water bodies. This was undoubtedly due to the presence of a narrow littoral reed belt (see Mattauch 1936, p.386, 427), which offered suitable conditions for the survival of the species preferring the above-mentioned mesotrophic conditions. In addition, this fact may explain the higher species diversity (55 taxa) found by 

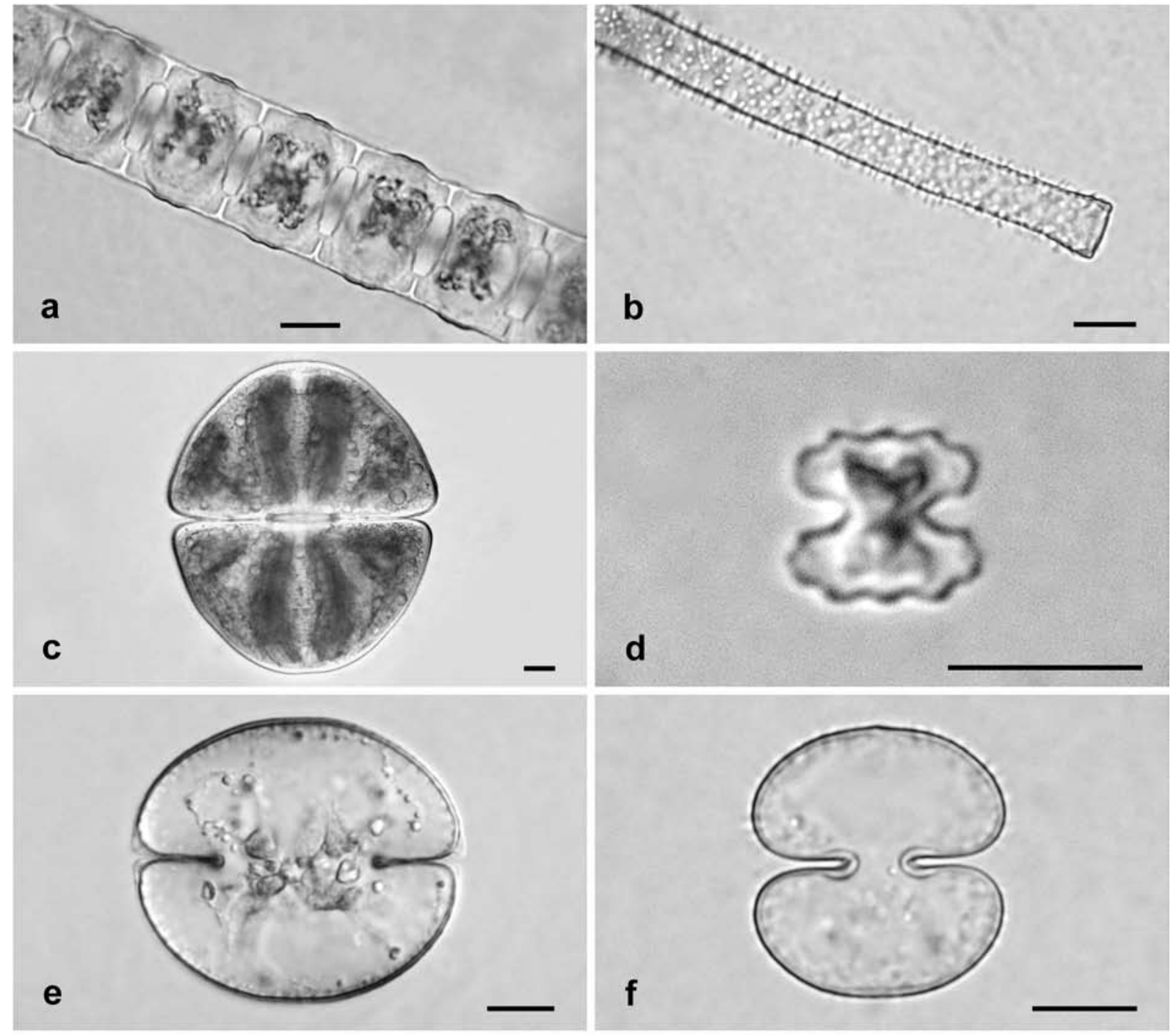

g
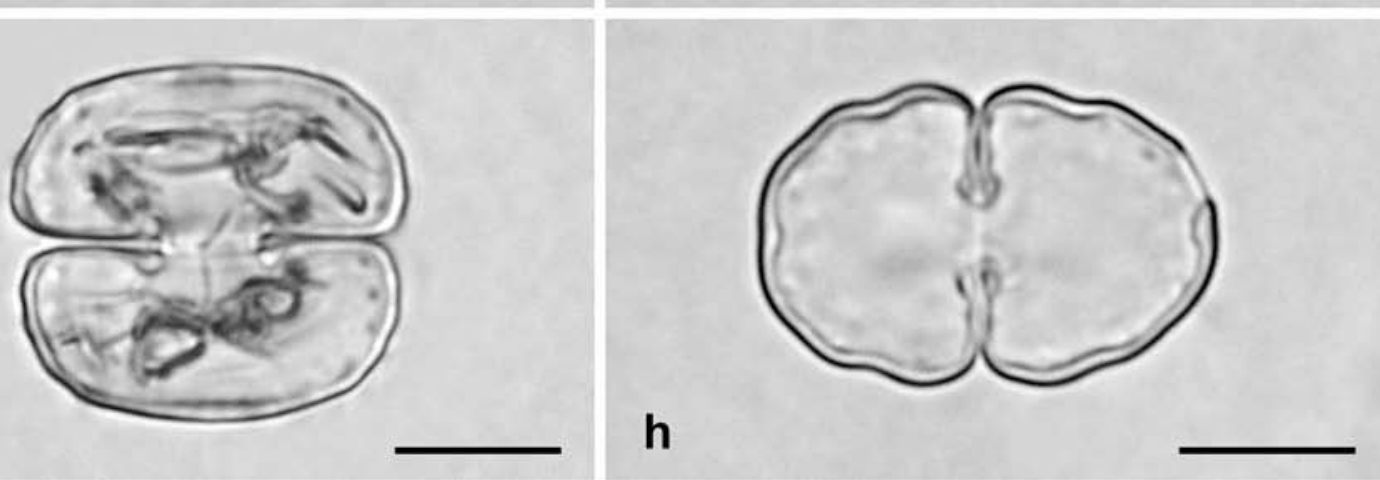

Fig. 4. (a) Desmidium baileyi var. caelatum; (b) Gonatozygon aculeatum; (c) Cosmarium ralfsii; (d) C. carinthiacum; (e) C. obsoletum; (f) C. ocellatum var. notatum; (g) C. tetrachondrum; (h) C. paragranatoides. Scale bar $10 \mu \mathrm{m}$.

Mattauch (1936). Desmids show the highest diversity in mesotrophic, slightly acidic water bodies (see e.g. CoEsel 1982, 1998) and, in general, at sites with distinct gradients in acidity and nutrient content.

However, even more interesting is the qualitative aspect of the comparison of the species composition: most of the ecologically highly sensitive species, characteristic of undisturbed, stable environment (Micrasterias oscitans, M. jenneri, Cosmarium ralfsii, Xanthidium armatum, Euastrum insigne, Staurastrum hystrix; see e.g. CoEsel 1998) have disappeared. In contrast, the relative distribution of the adaptive taxa with higher growth rates increased (see Table 1). This may produce evidence of lower stability of the biotope 
that is most likely caused by occasional overflow of the alkaline, highly eutrophic lake water into the locality (see Kalina \& PunČOCHÁŘová 1996). In the long-term aspect, it does not lead to significant increases in the $\mathrm{pH}$ and trophic state of the site due to the buffering capacity of the Sphagnum. However, it is very likely that such occasional disturbances may have caused the extinction of the most sensitive acidophilous species.

Despite the above-mentioned facts, the present ecological condition of the Swamp (with respect to the occurrence of desmids) seems to be rather favourable, and particularly the occurrence of some very rare taxa (see above) makes it a very valuable biotope.

\section{The small bog}

Looking at the composition of the desmid communities at the second site, the first remarkable feature is its very high species richness, which is particularly due to the large $\mathrm{pH}$ and trophy gradient and the high number of microhabitats available (see above). There is only one place among recently studied localities in the Czech Republic which has higher species richness: the Břehyně-Pecopala Nature Reserve (319 taxa, ŠŤASTNÝ, unpublished data). Also remarkable is the richness of the locality in rare taxa (102 taxa, i.e. $50 \%$, see Table 1). Moreover, the majority of the rare taxa found are characteristic and indicative of well-preserved, stable ecosystems (see COESEL 1998).

The rarest findings include Micrasterias oscitans, Pleurotaenium simplicissimum and Euastrum pinnatum. All these taxa are considered to be extremely rare in Central Europe (RŮžIČKA 1977, 1981). In the existing desmid checklists of various European countries (GUTOWSKI \& Mollenhauer 1996, Coesel 1998, Marhold \& HindÁk 1998, Kouwets 1999, AbDelahad et al. 2003, LeNZENWEGER 2003, PoulíčKovÁ et al. 2004) these taxa are either missing or their findings date from the $19^{\text {th }}$ or the early $20^{\text {th }}$ century, which makes it very likely that they are already extinct or close to extinction.

Another very remarkable fact is that all the 46 desmid taxa found at the Swamp were recorded also from the second site. In addition, the distribution of the representatives of Synurophyceae at both these sites (NĚMCOVÁ, pers. com.) is also very similar. This supports the impression that the two sites are very similar in character, and the hypothesis that the second site is a more varied and better preserved copy of the Swamp appears quite likely. This hypothesis is also supported by the much higher desmid species richness of this site as well as by the occurrence of most of the ecologically highly sensitive taxa that have already presumably disappeared from the Swamp (see above). Whereas only 18 of the 55 desmid taxa reported by MatтAUCH (1936) have recently been found in the Swamp (see Table $1)$, at the second site the number of shared taxa is much higher (42).

With respect to the occurrence of desmids, the above-mentioned facts clearly illustrate the uniqueness of the second site studied. But given the fact that a high nature value of a particular site, indicated by the composition of desmid communities, is usually a good indicator of its general biological value (COESEL 1998), I consider the second site one of the most valuable wetland habitats in the Czech Republic, deserving further detailed investigations. In addition, the present results fully justify the recent designation of the discussed site as a part of the Swamp Nature Reserve.

In the future, the results presented here may be used as a basis for comparative ecological studies aimed at the future development of both these sites.

\section{Acknowledgement}

Yvonne Němcová is acknowledged for information on occurrence of representatives of the class Synurophyceae at the sites discussed. The study was supported by the research project no. 21620828 of the Czech Ministry of Education, and by the Charles University Science Foundation B BIO 164/2006 grant.

\section{References}

Abdelahad, N., Bazzichelli, G. \& D‘Archino, R. (2003): Catalogo delle Desmidiaceae (Chlorophyta, Zygnematophyceae) segnalate in Italia. (A checklist of Desmids (Chlorophyta, Zygnematophyceae) reported in Italy). - 120 pp., Academia Nazionale delle Science detta dei XL, Roma.

Asmund, B. \& Kristiansen, J. (1986): The genus Mallomonas (Chrysophyceae).-Opera botanica 85: 5-128.

Coesel, P.F.M. (1982): Structural characteristics and adaptations of desmid communities. - J. Ecol. 70: 163-177.

Coesel, P.F.M. (1998): Sieralgen en Natuurwaarden. 
Table 1. List of all taxa found with data indicating their rarity and frequency of their occurrence at the localities studied [(S) Swamp; (B) neighbouring bog; (R) rarity within the Czech Republic; * species found by Mattauch (1936)].

\begin{tabular}{|c|c|c|c|}
\hline & $S$ & B & $\mathbf{R}$ \\
\hline Actinotaenium cruciferum (De BARY) TeILING & * & & \\
\hline Actinotaenium cucurbita (BRÉB.) TeILING & $2 *$ & 4 & \\
\hline Actinotaenium diplosporum (P.LundeLL) TEILING & & 1 & 1 \\
\hline Actinotaenium inconspicuum (W.et G.S.WeSt) TEILING & & 1 & 2 \\
\hline Actinotaenium perminutum (G.S.West) TeILING & 1 & 1 & 3 \\
\hline Actinotaenium silvae - nigrae (RABANus) Kouwets et Coesel & 2 & 1 & \\
\hline Actinotaenium turgidum (BRÉв.) TeILING & $*$ & 1 & \\
\hline Actinotaenium sp.1 & 1 & 2 & \\
\hline Actinotaenium sp.2 & & 1 & \\
\hline Bambusina brebissonii KüTZING ex KüTZING & $*$ & 2 & \\
\hline Closterium abruptum W.WEST & 2 & 2 & 1 \\
\hline Closterium acutum BRÉB. & 3 & 2 & \\
\hline Closterium angustatum RALFS & & 2 & 1 \\
\hline Closterium archerianum CLEVE & & 1 & 2 \\
\hline Closterium attenuatum RALFS & & 1 & \\
\hline Closterium baillyanum BRÉB. & 2 & 2 & \\
\hline Closterium baillyanum var. alpinum (VIRET) GRÖNBLAD & & 2 & \\
\hline Closterium calosporum var. brasiliense BøRGES. & & 2 & 3 \\
\hline Closterium closterioides var. intermedium (J.RoY et BISSET) RUZICKA & $*$ & 2 & 3 \\
\hline Closterium cornu RALFS & & 2 & 1 \\
\hline Closterium cornu var. upsaliense NORDST. & & 2 & 2 \\
\hline Closterium costatum RALFS & & 2 & \\
\hline Closterium cynthia DE Noт. & & 1 & \\
\hline Closterium delpontei (G.A.KLEBS) Wolle & & 1 & 3 \\
\hline Closterium dianae RALFS & $*$ & 2 & \\
\hline Closterium dianae var. arcuatum (BRÉB.) RABENHORST & & 2 & \\
\hline Closterium didymotocum RALFS & & 2 & 2 \\
\hline Closterium directum W.ARCHER & & 1 & 2 \\
\hline Closterium gracile RALFS & & 3 & \\
\hline Closterium intermedium RALFS & & 2 & \\
\hline Closterium juncidum RALFS & 2 & 3 & \\
\hline Closterium kuetzingii BRÉB. & * & 2 & \\
\hline Closterium limneticum LEMMERM. & & 1 & \\
\hline Closterium lineatum var. elongatum (RosA) CROASDALE & & 3 & \\
\hline Closterium lunula RALFS & & 3 & \\
\hline Closterium navicula (BRÉB.) LÜTKEM. & & 1 & \\
\hline Closterium nematodes var. proboscideum W.B.TURNER & & 1 & 3 \\
\hline Closterium parvulum NäGELI & $2 *$ & 2 & \\
\hline Closterium pronum BRÉB. & 1 & 2 & \\
\hline Closterium ralfsii var. hybridum RABENHORST & & 2 & \\
\hline
\end{tabular}


Table 1 Cont.

Closterium rostratum RALFS

Closterium setaceum RALFS

Closterium striolatum RALFS

Closterium tumidum var. nylandicum GRÖNBLAD

Closterium turgidum RALFS

Closterium venus RALFS

4*

Closterium cf. macilentum BRÉB.

Closterium cf. pusillum var. monolithum WITTROCK

Cosmarium amoenum BRÉB.

Cosmarium angulosum BRÉB.

Cosmarium blytii var. novae - sylvae W.et G.S.WEST

Cosmarium boeckii WILLE

Cosmarium botrytis var. mediolaeve W.WEST

Cosmarium carinthiacum LÜTKEM.

Cosmarium connatum BRÉB.

Cosmarium conspersum var. latum (BRÉB.) W.et G.S.WeST

Cosmarium contractum KIRCHNER

Cosmarium contractum var. ellipsoideum (ELFVING) W.et G.S.WEST

Cosmarium contractum var. minutum (DELPONTE) W.et G.S.WEST

Cosmarium contractum var. retusum (W.et G.S.WeSt) WILli KRIEG. et GerlofF

Cosmarium crenulatum NäGELI

Cosmarium debaryi W.ARCHER

Cosmarium difficile LÜTKEM.

Cosmarium formosulum HoFF

Cosmarium goniodes var. subturgidum W.et.G.S.WEST

Cosmarium granatum BRÉB.

Cosmarium humile (F.GAY) NORDST.

Cosmarium isthmochondrum NORDST.

Cosmarium jaoi Kouwets

Cosmarium margaritaceum MessiK.

Cosmarium margaritiferum RALFS

Cosmarium obsoletum (HANTZSCH) ReInsCH

31

Cosmarium obtusatum SCHMIDLE

Cosmarium ocellatum B.EICHLER et GuTw.

Cosmarium ocellatum var. notatum (Nordst.) Willi KRIEG. et Gerloff

Cosmarium ordinatum (BöRGES.) W.et.G.S.WEST

$\begin{array}{ccc} & 1 & 3 \\ & 2 & 3 \\ 2 * & 1 \\ & 2 & \\ & 1 & \\ & 2 & 3 \\ 1 & 3 \\ & 1 & 3 \\ & 2 & 2\end{array}$


Table 1 Cont.

Cosmarium pseudopyramidatum P.LundeLL

$2 *$

2

Cosmarium punctulatum var. subpunctulatum (NoRDST.) BöRGES.

Cosmarium pyramidatum BRÉB.

Cosmarium quadratulum var. boldtii (MESSIK.) WILli KRIEG. et GERLOFF

*

Cosmarium quadratum RALFS

2

Cosmarium quadrum P.LundeLL

Cosmarium quadrum var. sublatum (NoRDSt.) W.et.G.S.WeST

Cosmarium ralfsii BRÉB.

Cosmarium rectangulare GRUNOW

Cosmarium regnellii WILLE

Cosmarium reniforme (RALFS) W.ARCHER

Cosmarium retusum (PERTY) RABENHORST

3

Cosmarium sexnotatum var. tristriatum (LüTKEM.) SCHMIdLE

Cosmarium simplicius (W.et.G.S.WEST) GRÖNBLAD

Cosmarium subcostatum var. minus (W.et.G.S.WEST) FöRSTER

Cosmarium subcucumis Schmide

Cosmarium subgranatum (NORDST.) LÜTKEM.

Cosmarium subquadrans var. minor SyMOens ex COESEL

Cosmarium subtumidum NORDSTEDT

Cosmarium tetrachondrum P.LundeLL

Cosmarium tetraophthalmum BRÉB.

Cosmarium tinctum RALFs

Cosmarium vogesiacum LEMAIRE

Cosmarium wittrockii P.LundeLL

Cosmarium cf. pseudoretusum Ducell.

Cosmarium cf. tenue W.ARCHER

Cosmarium sp.1

Cosmarium sp. 2

Cylindrocystis brebissonii (RALFs) DE BARY

Cylindrocystis crassa DE BARY

Cylindrocystis gracilis I. HIRN

2

Desmidium aptogonum KüTZING

Desmidium baileyi var. caelatum (KIRCHNER) NorDST.

Desmidium swartzii RALFS

Euastrum ansatum RALFS

Euastrum ansatum var. rhomboidale F. DucELl.

Euastrum binale var. gutwinskii (SCHMIDLE) HomfELD

Euastrum biscrobiculatum (Wolosz.) Coesel

Euastrum denticulatum F.GAY

Euastrum dubium var. ornatum WoLosz. 
Table 1 Cont.

Euastrum germanicum (SCHMIDLE) WILLI KRIEG.

Euastrum humerosum RALFS

Euastrum insigne RALFS

Euastrum insulare var. silesiacum (GRÖNBLAD) WILLI KRIEG.

Euastrum luetkemuelleri var. carniolicum (LÜTKEM.) WILLI KRIEG.

Euastrum oblongum RALFS

Euastrum pectinatum RALFS

Euastrum pinnatum RALFS

Euastrum pulchellum BRÉB.

Euastrum subalpinum MESSIK.

Euastrum turneri W.WEST

Euastrum verrucosum RALFS

Gonatozygon aculeatum Hastings

Gonatozygon brebissonii DE BARY

Haplotaenium indentatum Kouwets, morpha

Haplotaenium minutum (RALFS) BANDO

Haplotaenium rectum (DelPONTE) BANDO

Hyalotheca dissiliens RALFS

Hyalotheca dissiliens var. tatrica RACIBORSKI

Mesotaenium macrococcum (A.BrAUN) J.Roy et BISSET

Micrasterias apiculata RALFS

Micrasterias crux - melitensis RALFS

Micrasterias denticulata var. angulosa (HANTZSCH) W.et G.S.WeST

Micrasterias fimbriata RALFS

Micrasterias jenneri RALFS

Micrasterias oscitans RALFS

Micrasterias papillifera BRÉB.

Micrasterias rotata RALFS

Micrasterias thomasiana var. notata (NORDST.) GRÖNBLAD

Micrasterias truncata BRÉB.

Micrasterias truncata var. quadrata BulNH.

Netrium digitus (BRÉB.) ItzIGS. et Rothe

Netrium interruptum (BRÉB.) LÜTKEM.

Netrium oblongum (DE BARY) LÜTKEM.

Penium cylindrus BRÉB.

Penium exiguum W.West

Penium spirostriolatum J.BARKER

Pleurotaenium archeri DelPONTE

Pleurotaenium ehrenbergii (RALFS) DE BARY

Pleurotaenium simplicissimum GRÖNBLAD

Pleurotaenium trabecula NÄGELI

Pleurotaenium truncatum (BRÉB.) NäGELI
2

2

12

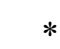

\begin{tabular}{|c|c|c|}
\hline & 1 & 2 \\
\hline 1 & 2 & 3 \\
\hline \multirow[t]{4}{*}{$*$} & 2 & \\
\hline & 2 & 1 \\
\hline & 1 & 3 \\
\hline & 2 & 3 \\
\hline \multirow[t]{2}{*}{1} & 1 & 1 \\
\hline & 1 & 3 \\
\hline \multirow[t]{3}{*}{$*$} & 1 & \\
\hline & 2 & 3 \\
\hline & 2 & \\
\hline 3 & 3 & 3 \\
\hline \multirow[t]{2}{*}{$*$} & 2 & 1 \\
\hline & 2 & 2 \\
\hline
\end{tabular}

$1 * \quad 2$

21

1

23

1

$2 \quad 2$

12

3* 3

* 1

1

2

2

$2 * \quad 2$

2

2

22

$*$

$1 * \quad 2$

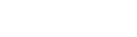

13

11

12

* 1

13

* 1

1
2* 2 
Table 1 Cont.

Pleurotaenium $\mathrm{sp}$.

Sphaerozosma filiforme RALFS

Spirotaenia cf. erythrocephala ITZIGS.

Staurastrum aculeatum RALFS

Staurastrum alternans BRÉB. in RALFS

Staurastrum brachiatum RALFS

Staurastrum controversum RALFS

Staurastrum dilatatum RALFS

Staurastrum eurycerum SKUJA

Staurastrum gracile RALFS

Staurastrum hirsutum BRÉB.

Staurastrum hirsutum var. arnellii (BOLDT) COESEL

Staurastrum hirsutum var. muricatum (BRÉB. ex RALFS) FÖRSTER

2

Staurastrum hystrix RALFS

Staurastrum inflexum BRÉB.

Staurastrum lapponicum (SCHMIDLE) GRÖNBLAD

Staurastrum margaritaceum RALFS

Staurastrum minimum COESEL

Staurastrum muticum RALFS

Staurastrum orbiculare var. depressum J.Roy et BISSET

Staurastrum pelagicum W.et G.S.WEST

Staurastrum polymorphum var. pygmaeum GRÖNBLAD

Staurastrum polytrichum (PERTY) RABENHORST

Staurastrum punctulatum BRÉB.

Staurastrum reinschii RoY

Staurastrum scabrum BRÉB.

Staurastrum simonyi HeIMERL

Staurastrum teliferum RALFS

Staurastrum tetracerum RALFS

Staurastrum vestitum RALFS

$*$

$2 \quad 2$

Staurastrum cf. boreale W.et G.S.WEST

Staurastrum cf. crenulatum var. continentale MESSIK.

Staurodesmus controversus (W.et G.S.WEST) TEILING

Staurodesmus convergens (RALFS) S.LILL.

Staurodesmus cuspidatus (RALFs) TEILING

Staurodesmus dejectus var. apiculatus (BRÉB.) TEILING

Staurodesmus extensus var. isthmosus (HEIMERL) COESEL

Staurodesmus glaber (RALfs) TeILING

Staurodesmus incus (BRÉB.) TEILING

Staurodesmus omearae (W.ARCHER) TEILING

Staurodesmus triangularis var. subparallelus (

Teilingia excavata var. subquadrata (W.et G.S.WEST) STEIN

(1)

1

$1 \quad 1$

$\begin{array}{ccc} & 1 & 1 \\ & 1 & \\ 1 & 1 & \\ & 1 & 2 \\ & 1 & \\ & 2 & 2 \\ & 1 & 1 \\ & 1 & 1 \\ & 2 & 1\end{array}$


Table 1 Cont.

Teilingia granulata (J.Roy et BiSSET) BOURRely

Tetmemorus granulatus RALFS

2

Tetmemorus laevis RALFS

Tetmemorus laevis var. minutus (DE BARY) PlayfaIR

Xanthidium antilopaeum (BRÉB.) KÜTZING

Xanthidium antilopaeum var. planum RolL

Xanthidium armatum RALFS

Xanthidium cristatum BRÉB.

3

$2 * \quad 3$

$4 * 4$

$2 * 3$

- 56 pp., Uitgeverij Koninklijke Nederlandse Natuurhistorische Vereniging, Utrecht.

Coesel, P.F.M. (2001): A method for quantifying conservation value in lentic freshwater habitats using desmids as indicator organisms. Biodiversity and Conservation 10: 177-187.

Coesel, P.F.M. (2003): Desmid flora data as a tool in conservation management of Dutch freshwater wetlands. - Biologia 58: 717-722.

Coesel, P.F.M., Kwakkestein, R. \& Verschoor, A. (1978): Oligotrophication and eutrophication tendencies in some Dutch moorland pools, as reflected in their desmid flora. - Hydrobiologia 61: 21-31.

Gutowski, A. \& Mollenhauer, D. (1996): Rote liste der Zieralgen (Desmidiales) Deutschlands, Schr. - R. f. Vegetationskunde 28: 679-708.

HaŠler, P., ŠTĚPÁnKovÁ, J., ŠPAČKovÁ, J., Neustupa, J., Kitner, M., Hekera, P., Veselá, J., Burian, J. \& PoulíčKovÁ, A. (2008): Epipelic cyanobacteria and algae: a case study from Czech ponds. Fottea 8: 133-146.

KalinA, T. (1969): Submicroscopic structure of silica scales in some Mallomonas and Mallomonopsis species. - Preslia 41: 227-228.

Kalina, T. \& PunčochÁŘovÁ, M. (1996): Algologický průzkum NPP Swamp. - 9 pp., Zpráva vypracovaná pro Agenturu ochrany prrírody a krajiny ČR, Praha.

Kouwets, F.A.C. (1991): Notes on the morphology and taxonomy of some rare or remarkable desmids (Chlorophyta, Zygnemaphyceae) from SouthWest France. - Nova Hedwigia 53: 383-408.

Kouwets, F.A.C. (1999): A check - list of Desmids (Chlorophyta, Zygnemaphyceae) of France. - Patrimoines naturels (M.N.H.N./S.P.N.) 41: $1-150$.

LenZenweger, R. (1996): Desmidiaceenflora von Österreich, Teil 1. - In: CRAMER, J. (ed.): Bibliotheca Phycologica 101. - 162 pp., Gebrüder Borntraeger Verlagsbuchhandlung, Berlin-Stuttgart.
Lenzenweger, R. (2003): Desmidiaceenflora von Österreich, Teil 4. - In: CRAMER, J. (ed.): Bibliotheca Phycologica 111. - 87 pp., Gebrüder Borntraeger Verlagsbuchhandlung, Berlin-Stuttgart.

MARHOLD, K. \& HindÁK, F. (1998): Zoznam nižších a vyšších rastlín Slovenska. (Checklist of non vascular and vascular plants of Slovakia). -687 pp., Veda, Bratislava.

Mattauch, F. (1936): Ein Beitrag zur Kenntniss der Verlandungserscheinungen am Hirschberger Grossteich. - Beih. Bot. Cbl. 54: 377-428

NovÁkovÁ, M. \& Popovský, J. (1972): Dicranochaete bohemica, sp. nova. - Arch. Protistenkde. 114: 37-45.

PAscher, A. (1909): Der Grossteich bei Hirschberg in Nordböhmen. I. Chrysomonaden. - Internat. Tev. Gesamt. Hydrobiol. Hydrograf. Monograph. Und Abhandl. 1: 1-66.

Pascher, A. (1939): Heterokonten. - In: Rabenhorst, L. (ed.): Kryptogamenflora Deutschlands, Österreich und der Schweiz, Bd. 11. - 480 pp., Leipzig.

Pfiester, L.A. \& Popovský, J. (1979): Parasitic, amoeboid Dinoflagellates. - Nature 379: 421424.

Popovský, J. \& Pfiester, L.A. (1990): Dinophyceae (Dinoflagellida). - In: Ettr, H., GerlofF, J., Heying, H. \& Mollehauer, D. (eds): Süsswasserflora von Mitteleuropa, Bd. 6. - 272 pp., Gustav Fischer Verlag, Jena - Stuttgart.

PoulíčKovÁ, A, Lhotský, O. \& Dř́malová, D. (2004): Prodromus sinic a řas ČR. - Czech Phycology 4: 19-33.

RŮŽIČKA, J. (1977): Die Desmidiaceen Mitteleuropas, Band 1, 1. Lieferung. - 292 pp., E. Schweizerbart'sche Verlagsbuchhandlung, Stuttgart.

RŮŽIČKA, J. (1981): Die Desmidiaceen Mitteleuropas, Band 1, 2. Lieferung. - pp. 293-736, E. Schweizerbart'sche Verlagsbuchhandlung, Stuttgart.

Stojanovski, P. \& Kalina, T. (1989): Diatom flora and syntaxonomy of an oligotrophic - dystrophic 
algal community in a nature reservation Swamp (Doksy, Northern Bohemia). - Preslia 61: 97105.

ŠmEK, O. (1997): Changes in desmid flora of the nature reserve „Řežabinec“ in South Bohemia after 30 years of intense environmental agriculture. Algological Studies 87: 59-85.

ŠŤASTNÝ, J. (2005): Diverzita a ekologie krásivek ve vybraných oblastech České republiky. - 83 pp., Dipl. Thesis, Charles University, Faculty of Science, Prague.

ŠŤASTNÝ, J. (2007): Die Desmidiaceenflora von Pískovny Cep (Südböhmen). - Novitates Botanice Universitatis Carolinae 18: 53-62.

ter BraAk, C.J.F. \& Šmilauer, P. (1998): CANOCO references manual and user's guide to Canoco for Windows. Software for Canonical Community Ordination (version 4). CPRODLO, Wageningen.

(C) Czech Phycological Society

Received June 24, 2008

Accepted October 15, 2008 